\title{
Development of Micro, Small and Medium Enterprises (MSMEs) Based on Creative Economy (EKRAF) and Gig Economy in Gorontalo Regency
}

\author{
Felmi D. Lantowa, Joice Machmud \\ *Corresponding Email: felmi.lantowa@umgo.ac.id \\ ${ }^{1}$ Gorontalo Muhammadiyah University, Indonesia \\ Received: November 4, 2020 \\ Revised: November 23, 2020 \\ Accepted: November 30, 2020
}

\section{Abstract}

The purpose of this study is to determine the development of MSMEs in Gorontalo Regency and to provide new innovations in the development of MSMEs based on Creative Economy (Ekraf) and Gig economy in Gorontalo Regency. This study uses a descriptive qualitative approach, which describes and describes facts according to the phenomenon of how development is seen from the strengths, weaknesses, threats and opportunities (SWOT analysis) with the aim of providing an Creative Economy-based MSME development strategy and the Gig economy in Gorontalo Regency. Data collection was carried out through observation, interviews and documentation about the strengths, weaknesses, opportunities, and threats of MSMEs against informants from three business fields, namely the Food Business Sector (dodol processed food), clothing (Sulaman Karawo) and handicrafts spread across three existing sub-districts in Gorontalo Regency. The results showed that the creative economybased and gig economy-based MSMEs in Gorontalo Regency have not been fully implemented by MSME actors because they have limited capabilities and experience problems in their business development, this is due to several problems faced such as limited capital, raw materials and the use of simple production equipment, limited marketing media due to the absence of a MSME center, the types of products offered, quite a lot of transaction costs, less skilled labor, and product copyright registration problems for that from the results of the SWOT analysis of the diversification strategy at a more precise value to be applied, because it is considered more appropriate to the current conditions in Gorontalo Regency. In addition, the use of the gig economy is a part-time worker who is competent and innovative for MSMEs that are progressing and ready to compete.

Keywords: MSME, Creative Economy, Gig Economy

\section{Introduction}

Economic development in Indonesia began in 1997, marked by the occurrence of reformation events that caused the economy to collapse until it reached its lowest point in the history of the nation's economy. The collapse of the economy at this time almost caused Indonesia to split into a Balkan country. In line with Indonesia's reforms, Indonesia's economy was also reformed from an authoritarian economic system to a democracy, from a centralized economy to a decentralized economy. So that the vision of 2025 as a new paradigm for the Indonesian economy will concentrate more on an economy based on national and natural resources. One of them is by empowering Micro, Small and Medium Enterprises (UMKM) among the community (Santosa, 2013).

MSME has a role in development and economic growth, MSME also has a very important role in overcoming the problem of unemployment (Robson \& Bennett, 2000; Katyal \& Xaviour,

Copyright $\odot$ (2020, Journal of Asian Multicultural Research for Economy and Management Study, Under the license CC BY-SA 4.0 
2015). The growth of micro enterprises has made it a source of growth in employment and income opportunities. By absorbing a lot of labor, it means that MSMEs also have a strategic role in the government's efforts to fight poverty and unemployment. The contribution of the micro, small and medium enterprises sector to gross domestic product increased from $57.84 \%$ to $60.34 \%$ in the last five years. The labor absorption in this sector also increased from $96.99 \%$ to $97.22 \%$ in the same period. Realizing the importance of the contribution of MSMEs in improving a positive economy in Indonesia, the government provides a policy of increasing capital and training for MSME players so that it is hoped that MSME players can produce creative products and be able to compete in the era of the Asean Economic Community (MEA) and the era of industrial revolution 4.0. Creative economy or what is often referred to as EKRAF is an industry that relies on talent, skills and creativity which are the basic elements of every individual. In this case the creative economy development model is thought to be very appropriate to be applied in MSMEs in Indonesia, especially in areas that have natural resource potential and in expansion areas such as Gorontalo Regency.

Gorontalo Regency is known as one of the longest regencies in Gorontalo Province as a result of the division of North Sulawesi Province which was formed by the customary agreement "Limo Lo Pohala'a" with four elements, namely territory, people, government and sovereignty. Gorontalo Regency also has the most potential resources in Gorontalo Province. This can be seen from the many industrial companies located in Gorontalo Regency.

Table 1. Number of Companies, Labor, Investment and Production Value of Micro and Small Industries by Regency / City in Gorontalo Province

\begin{tabular}{|c|l|l|c|c|c|}
\hline No. & Regency/City & $\begin{array}{c}\text { Number of } \\
\text { Companies }\end{array}$ & Labor & $\begin{array}{c}\text { Investment } \\
\text { (Million } \\
\text { Rupiah) }\end{array}$ & $\begin{array}{c}\text { Production } \\
\text { Value } \\
\text { (Million } \\
\text { Rupiah) }\end{array}$ \\
\hline 1 & Boalemo & 874 & 2639 & 18883,43 & 159792,49 \\
\hline 2 & Gorontalo & 3442 & 9549 & 76189,23 & 217035,92 \\
\hline 3 & Pohuwato & 1989 & 4332 & 21835,34 & 53845,45 \\
\hline 4 & Bone Bolango & 2664 & 6459 & 10603,56 & 24689,65 \\
\hline 5 & Gorontalo Utara & 2493 & 5965 & 17030,85 & 88953,68 \\
\hline 6 & Gorontalo City & 2926 & 6582 & 48095,54 & 159792,49 \\
\hline
\end{tabular}

Source: BPS Gorontalo Province, 2017

From the table above, it can be seen that Gorontalo Regency is the Regency with the highest level of industry, investment and production in Gorontalo Province, in Gorontalo Regency until now it has developed approximately thirty-nine thousand MSMEs with five business fields, namely the chemical industry and industrial materials, business fields. the food industry, the clothing industry, the metal and electronics industry and the handicraft industry.

However, according to research conducted by Payu (2013) regarding the mapping of MSMEs in Gorontalo Province, the results of the research are seen from the product competitiveness and mastery of information technology for MSMEs in Gorontalo Province which is relatively low, so that the products produced by MSMEs are less desirable and it is difficult to compete in the market, especially for certain segments, considering that the current era has entered the era of the industrial revolution 4.0. In this era, the industry has changed a lot. Many permanent workers have been replaced by freelancers or freelancers. The change is described in the term Gig Economy. 
Gig Economy means an economic condition in which there is a shift in the status of company workers, who are generally permanent workers to short-term contract employees, independent workers and non-permanent employees. This system refers to the term rampant freelance workers, or staff recruited for short-term projects, or just when needed (Abraham et al., 2017; Johnston \& Land-Kazlauskas, 2018; Rahman et al, 2019).

The use of freelancers who have abilities is not much different from permanent workers, they can reduce the expenses that should be given to permanent workers (health insurance, holiday allowances, and so on). Such a system is considered to be able to reduce inequality in the labor market.

This also occurs in Gorontalo Regency, the number of MSME industries in this Regency does not have a significant impact on reducing the poverty of its people, this can be seen from the 2017 BPS data for Gorontalo Regency as follows.

Table 2. Number of Poor People in Gorontalo Regency

\begin{tabular}{|c|c|c|}
\hline Year & Poverty Line & $\begin{array}{c}\text { Number of Poor Population (Thousands } \\
\text { of People) }\end{array}$ \\
\hline 2017 & 382,722 & 76.93 \\
\hline 2016 & 368,863 & 78.36 \\
\hline 2015 & 343,373 & 80.52 \\
\hline
\end{tabular}

Source: BPS Gorontalo Province, 2017

Based on the facts and phenomena described above, the researcher wants to further investigate the development of Micro, Small and Medium Enterprises (MSMEs) based on the Creative Economy (Ekraf) and the Gig economy in Gorontalo Regency.

\section{Methods}

This study uses a descriptive qualitative research approach in terms of strengths, weaknesses, threats and opportunities (SWOT analysis). The research location is UMKM in Gorontalo Regency. The selection of informants is based on the criteria, namely first that they have been in business for at least five years, second, namely the most stable informants in their respective fields and those who still exist in Gorontalo Regency in the following order: the food industry (dodol processed food) in Isimu District, clothing business (Sulaman Karawo) in Telaga District and the handicraft industry (Kopiah Karanji) in Bongomeme District. Secondary data in this case is complementary taken from other sources. Namely, the profile of the research location, the state of the facilities and infrastructure.

To obtain data in this study, the authors used data collection procedures: Observation, Interview and Documentation. Data validity checks are carried out by in-depth observation, triangulation, peer discussion, negative case analysis, tracking the suitability of results and checking members, consisting of data credibility testing, dependability testing and audit trail testing in accordance with Moleong's (2006) opinion that in checking the validity of the data includes 3 aspects, including:

\section{Credibility Test}

The credibility of the data aims to prove whether the data that has been collected is reliable, then the following things are done: triangulation, member checks, conducting observations, discussing data, in-depth observations, case analysis and checking interpretations and conclusions on the results of data and documents. 
Dependability Test. The analysis was carried out by conducting continuous interviews with the same informant at different times, then the results were analyzed, if the results were the same, it meant that the data could be trusted. The audit trail test is carried out with the intention of checking the correctness of the entire research process and stages.

\section{Results and Discussion}

\section{Development of Micro, Small and Medium Enterprises (MSMEs) based on Creative Economy (Ekraf) in Gorontalo Regency}

\section{Production}

In developing UMKM, production is the main activity, production itself is a process of transforming input into output, but the definition of production in the view of economics is much broader. The definition of production includes the objectives of the activity to produce output and the characters attached to it.

Creative economy-based MSME actors in Gorontalo Regency also revealed obstacles in obtaining raw materials. Mrs. Hj. Iko Mantalo as the owner of the Naga Mas UMKM said that:

"In obtaining raw materials for the manufacture of openwork fabrics, this company orders directly from Surabaya in the form of plain cloth and yarn which are the main raw materials for the manufacture of openwork fabric products.

The problem of limited raw materials experienced by MSME players is because they have to import from outside the region for raw materials. This is also due to the absence of a MSME center that provides raw materials in Gorontalo Regency. Another problem was disclosed by Bpk. Suranip Abdul, who revealed the issue of MSME raw materials as follows:

"The raw materials for this production depend on the farmers, such as during the Covid 19 pandemic, raw materials are difficult to obtain because their farmers are afraid to leave the house"

Meanwhile, the equipment used is still very simple, this is also related to the local wisdom of the product: this is as expressed by Mrs. Hj. Iko Mantalo as the owner of the Naga Mas MSME said that:

"Our equipment is still simple, so the production process is still manual without the help of machines, for example, to embroider patterns, we still use a scaling tool. Apart from that, different craftsmen do the work of slicing threads, pulling threads, and tie Karawo. Therefore, it is necessary to maintain the quality of each stage of production".

The same thing was conveyed by Mr. Suranip Abdul who revealed that:

"For the raw material of water hyacinth, you still use your hands to knit it while the raw materials for rattan and banana petals are already using the machine".

This statement shows that the problem of using simple production equipment is also an obstacle for them in carrying out the production process which has an impact on the production capacity they produce.

\section{Markets and Marketing}

For marketing itself, the problem faced by creative MSME actors in Gorontalo Regency is that there is no place for actualization. This was stated by Mrs. Hj. Iko Mantalo follows:

"we do not put our karawo products into shops, but we sell them here, at the

Copyright $\odot$ 2020, Journal of Asian Multicultural Research for Economy and Management Study,

Under the license CC BY-SA 4.0 
production house"

"For the market for rattan and water hyacinth products it is difficult to sell in Gorontalo, for that I send most of my products to Manado and Bitung"

"For tuna and sagela shredded products, I still input them at the Agung supermarket because if they are included in other supermarkets such as Alfamart and Indomart, the cost for the results is a lot".

"For dodol we sell it at the airport, the rest we make dodol if there is an order".

"In Gorontalo Regency, there is no place that provides raw materials and also a special place that sells UMKM products"

\section{Management and Finance}

The results showed that for the management and finance of UMKM, Ekraf experienced problems with management of production costs and also additional costs for developing their business, because from the results of the interviews we conducted there were a number of other expenses outside of production costs which were considered quite a lot for MSME players. As expressed by Mr. Suranip

"for finance we still use our own capital and the proceeds from the sale of our products, and we also experience problems related to the price of our products because we have to bear shipping costs for our products out of town".

"For our costs, it is very difficult because the rental prices at the airport where we market the product are expensive, this makes it difficult for us to develop our business.".

\section{Government Policy}

In promoting creative economy-based MSMEs it requires cooperation from various parties, especially support from the government, this can be seen from the policies issued by the government itself, both from the ease of obtaining raw materials, production to the marketing process. From interviews that have been conducted with MSME players, so far government support for MSME players is still in terms of local promotion of products at government events such as at exhibitions held by the government, as told by Mr. Sunarto as Head of the HR and SME development section of Gorontalo Regency.

"Government support for UMKM in Gorontalo Regency is in the form of promotion, capital and also training for MSME players"

"Government policy for MSMEs is still limited to promotion for our products, not including the convenience for us in obtaining raw materials and paying income tax"

"The role of the government is still limited to participating in the exhibitions being held. There is no policy in terms of managing business permits, especially in granting halal certificates and the convenience of renting business premises and we have difficulty getting information about the implementation of ifen-ifen involving MSMEs".

Creative economy-based MSMEs must always maintain quality and increase their creativity and innovation in producing new works. Increasing creativity for MSME actors can be done through a series of training processes from the government such as business management, marketing management, finance, and so on.

\section{Economic Conditions}


These creative-based MSMEs have very many benefits for economic development in the regions because the results of these MSMEs can absorb labor so as to reduce unemployment, use local materials and can increase regional income and can raise the characteristics of the region itself,

"with the existence of this UMKM we can get additional income, counting on helping our husbands"

"Because the raw materials are rattan and water hyacinth, with this furniture business, water hyacinth which was a problem for Limboto Lake because it causes shallowness of the lake can be utilized and can be used as additional income for the people around Limboto Lake".

"This karawo business has helped approximately 300 housewives whose status is URT to get additional income for family needs".

\section{Environment}

In carrying out a business and / or activity planned for the environment, a company must pass an Environmental Impact Analysis (AMDAL) test. AMDAL aims to avoid impacts, minimize impacts, and mitigate / compensate for impacts. AMDAL as an "environmental safe guard" is useful for regional development, as a guideline for environmental management, fulfillment of debt prerequisites (loan), and recommendations in the licensing process. As expressed by Mrs. Lira

"My business has not done an EIA test but to dispose of this processed fish waste I have prepared a place, the plan is that if my business is large and growing I will propose to conduct an AMDAL test by related parties".

There are 2 (two) types of permits in Article 1 of Law Number 32 of 2009 concerning Environmental Protection and Management (UUPPLH), namely first, an environmental permit is a permit that is granted to every person carrying out a business and / or activity that is subject to an Amdal or UKL-UPL in the framework of environmental protection and management, which is a prerequisite for obtaining a business and / or activity license. Second, a business and / activity license is a license issued by a technical agency to conduct business and activities. In line with Article 40 that an Environmental Permit is a requirement for obtaining a business and activity permit.

\section{Development of Micro, Small and Medium Enterprises (MSMEs) based on Gig economy in Gorontalo Regency}

\section{Obtaining independent professional workers to be employed}

In the recruitment of competent employees, they must go through a selection guided by the required HR qualifications. The qualifications required consist of general and specific qualifications. General qualifications, namely the need for human resources that can be used in general for all types of business activities, including MSMEs such as general knowledge, health, good personality, intelligence, seriousness, and commitment. Special qualifications, namely the need for human resources that are only needed for certain types of work (not everyone can do it), such as the ability to make karawo embroidery, making rattan and water hyacinth carvings and those who can manage shredded food. In the application, MSMEs in Gorontalo Regency do recruitment without expertise and education requirements. This is in accordance with the results of the interview we conducted with Mr. Suranip

"in recruiting employees I don't see Education but if they want to work please, for me

Copyright $@$ (2020, Journal of Asian Multicultural Research for Economy and Management Study, Under the license CC BY-SA 4.0 
a matter of expertise second affairs ".

The same thing was also expressed by Mrs. Hj. Iko

"The workers I employ are housewives who work as URT and they do not have previous skills related to karawo, when they start working here they will be trained how to embroider and make patterns".

From these results, in the recruitment of MSME workers, they do not have a minimum standard of either education or expertise.

\section{Potential to save costs}

In terms of MSME development, from a gig economy perspective, entrepreneurs must pay attention to cost efficiency, especially in terms of recruiting employees or workers who will be employed in the place of business. This has been done by the UMKM actors themselves, as expressed by Mrs. Hj. Iko

"In recruiting employees, we look at business capabilities, if they are able to pay for workers' salaries, as during the Covid event, many employees did not do embroidery activities"

"In recruiting employees, I look at their financial capabilities and orders, as during the Covid event, we homed many workers".

\section{flexible working time}

Gig economy sector consisting of professional workers who work independently where they accept jobs from single short-term projects, from companies and non-profit organizations as well as individuals in developing the gig economy must pay attention to flexible working times and this has also been implemented by UMKM. As Mr. Suranip said

"There are no permanent workers here except for the administrative part, the rest is all contract system"

"We do not have permanent employees. In the future, there will be new orders, we will recruit employees".

From the MSME statement in Gorontalo Regency, the employee system they use is not fixed but uses a contract system, so according to production, this can provide budget efficiency for MSMEs.

\section{Creativity and Innovation}

In developing MSMEs by utilizing the gig economy, entrepreneurs and workers are required to have creativity and innovation, especially in developing their products. Not all creative MSMEs in Gorontalo Regency employ employees who have the creativity and innovation needed so that these products are able to compete. This is in accordance with the results of an interview with the informant, Ibu Tarni

"For this dodol packaging we still use simple ingredients, namely woka leaves and after that it is packaged in used cardboard boxes, here we add a business identity label in front of the box. As for marketing, we haven't used social media yet ".

"For the pattern of shells and materials, we still like the usual patterns with floral motifs, while for marketing we are still only subscribers who know this place".

However, Mrs. Lira did different things 
"For packaging, the idea is for me and my husband to make us choose materials that can be reused, while for marketing we use existing social media so that our products have reached outside Gorontalo"

\section{SWOT}

\section{Internal Factors (Strengths and Weaknesses)}

There are several internal factors that have been identified as the strengths of the economic economy-based MSME development strategy in Gorontalo Regency, namely; Convenience of strategic location and place; Relatively affordable prices; Raw materials are always available; Model variations, patterns, carvings and flavors; types of companion products offered; Good communication and familiarity of employees. Once identified, there are also several internal factors that become the weaknesses of the MSME development strategy, namely: (1) Limited capital. (2) Weak business management systems. (3) Limited quality and quantity of human resources. (4) Marketing (promotion) which is not yet intensive. (5) supporting production tools are still limited.

\section{External factors (Opportunities and Threats)}

The opportunities for an economic-based economy-based MSME development strategy in Gorontalo Regency are support from the government; technology and information development; business expansion (expansion); Good relations and customer loyalty. Meanwhile, the threats to the MSME development strategy are unstable raw material prices; the emergence of new competitors with the same product; competitors that offer different products; location of MSMEs that are difficult to reach.

MSMEs based on creative economy and gig economy in Gorontalo Regency have not been fully implemented by MSME actors because they have limited capabilities and experience problems in developing their business. This result is in line with research conducted by Payu (2013) which reveals that from the perspective of product competitiveness and mastery of information technology, MSMEs in Gorontalo Province are relatively low, so that the products produced by MSMEs are less desirable and difficult to compete in the market, especially for certain segment. This occurs due to several problems faced by creative MSMEs in Gorontalo Regency, including limited capital problems, simple raw materials and use of production equipment, limited marketing media because there is no MSME center, types of products offered, quite a lot of transaction costs, labor unskilled work, and their copyright registration problems. The solution from the government for the advancement of creative MSMEs in Gorontalo Regency is to anticipate the future which is continuous by providing additional capital to MSME players.

In the theory stated by Hartomo \& Cahyadin (2013) on indicators of the sustainability of the creative economy in the creative industry, attention must be paid to: Production, Markets and Marketing, Management and Finance, Government Policy, Economic Conditions. However, from the results of the survey and direct interviews to the research location, the researchers concluded that to develop an eco-based and gig economy-based MSMEs, these MSMEs are very difficult, because:

\section{Production}

In the production of MSMEs in Gorontalo Regency, they still use makeshift raw materials obtained from outside the region as well as from local farmers. The difficulty in obtaining these raw materials is also an obstacle faced by business actors. This raw material is the most important element that determines the quality of the product produced. As expressed by

Copyright @ 0 2020, Journal of Asian Multicultural Research for Economy and Management Study, Under the license CC BY-SA 4.0 
Wilantara \& Susilawati (2016) states that the demand to follow design standards and product quality in order to comply with the provisions demands changes in the production and marketing activities of MSMEs. In the MEA, member countries agree to implement the ISO26000 standard

\section{Markets and Marketing}

From a market and marketing perspective, the existing UMKM in Gorontalo Regency still faces problems, namely, the absence of a center or place that is specially provided as a container for MSME products to be marketed. Meanwhile, in Indonesia itself, there are regulations regarding the Indonesian National Standard on the Market itself.

\section{Management and Finance}

MSMEs in Gorontalo Regency also experience difficulties in developing and producing creative and competitive products because they still have funds from the owners without additional budget from financing or assistance from the government. Where capital is an important element in developing a business as revealed by Tejasari (2008) capital is the main factor needed to develop a business unit.

\section{Government policy}

The government policy for the development of MSMEs in Gorontalo Regency already exists but this policy is still general in nature, namely related to providing capital, promotion in limited events, namely government events, and training. The problems with MSMEs are constrained by the processing of permits which according to MSME actors is burdensome, knowledge related to the use of electronic media so that their products can be known or widely spread and also the need for workers who are competent in terms of creativity and innovation for the development of MSMEs itself .

\section{Economic Conditions}

MSMEs in Gorontalo Regency have the potential to contribute more to regional progress and can be a solution to the problems of unemployment and poverty that exist in this area. This can be seen from the absorption of labor by MSMEs who recruit or employ local communities and the raw materials used are raw materials that come from the surrounding environment.

\section{Environment}

Environmental impacts caused by the existence of MSMEs also need to be considered because the environment is one of the factors that guarantee the quality of the products produced. Creative MSMEs are also seen whether they are environmentally friendly so that they can provide positive values for the surrounding environment.

\section{A creative and innovative workforce who is able to reduce costs}

In the development of eco-based MSMEs and in particular the gig economy, the workforce is a determining element for the development of MSMEs, because the utilization of part-time labor will make cost efficiency and a workforce that has innovation and creativity will enable these businesses to compete in the future and adapt to market developments and demands.

Judging from the SWOT analysis related to the strengths, weaknesses, opportunities and threats of developing MSMEs based on Creative Economy (Ekraf) and the Gig economy in Gorontalo Regency, there are several strategies that can be carried out by looking at the results of interviews with informants related to the development of eco-based and gig economy-based MSMEs. Ekraf-based and gig economy-based MSMEs are in quadrant one. This position 
illustrates that the business has the opportunity / potential to be developed because it has its own characteristics, the strategic recommendation given is Progressive, by maximizing existing opportunities, namely easy access to marketing using technological developments and additional capital from the government, this is done for expansion, enlarging growth and achieve maximum progress for the MSMEs in Gorontalo Regency. The following is an overview regarding the SWOT analysis.

\section{SWOT Analysis Matrix}

\begin{tabular}{|c|c|c|}
\hline Internal Factor & $\begin{array}{l}\text { Strengths (S) } \\
\text { 1. Comfort Place and strategic location } \\
\text { 2. Relatively affordable prices } \\
\text { 3. Raw materials are always available } \\
\text { 4. Variations in models, patterns, } \\
\text { carvings and flavors } \\
\text { 5. Types of companion products } \\
\text { offered } \\
\text { 6. Communication and familiarity of } \\
\text { employees that are established good }\end{array}$ & $\begin{array}{l}\text { Weakness (W) } \\
\text { 1. Limited capital } \\
\text { 2. Weak business management } \\
\text { system } \\
\text { 3. Limited quality and quantity } \\
\text { of human resources } \\
\text { 4. Less intensive marketing } \\
\text { (promotion) } \\
\text { 5. Supporting production tools } \\
\text { are still limited }\end{array}$ \\
\hline $\begin{array}{l}\text { Opportunity (O) } \\
\text { 1. Support from the } \\
\text { government } \\
\text { 2. Technology and } \\
\text { information } \\
\text { development } \\
\text { 3. Business expansion } \\
\text { (expansion) } \\
\text { 4. Good relations and } \\
\text { customer loyalty }\end{array}$ & $\begin{array}{l}\text { SO Strategy } \\
\text { 1. Innovating and product variations in } \\
\text { attracting and growing customer } \\
\text { loyalty and supporting future } \\
\text { business expansion. customers } \\
\text { 2. Increase business potential by } \\
\text { utilizing strategic locations and } \\
\text { developments in access to } \\
\text { technology and information. } \\
\text { 3. With government support, the } \\
\text { production and sales process can be } \\
\text { maximized, and the stability of the } \\
\text { selling price can be maintained. }\end{array}$ & $\begin{array}{l}\text { WO strategy } \\
\text { 1. Limited capital and } \\
\text { production support tools can } \\
\text { be overcome with financial } \\
\text { assistance from the } \\
\text { government } \\
\text { 2. Improve and tighten the } \\
\text { management system and } \\
\text { employee recruitment so as } \\
\text { not to obstruct business } \\
\text { progress. } \\
\text { 3. Maximizing the use of } \\
\text { promotional media such as } \\
\text { print and electronic media to } \\
\text { reach more consumers. }\end{array}$ \\
\hline $\begin{array}{l}\text { Threats }(\mathrm{T}) \\
\text { 1. Unstable raw material } \\
\text { prices } \\
\text { 2. The emergence of new } \\
\text { competitors with the } \\
\text { same product } \\
\text { 3. The emergence of } \\
\text { competitors offering } \\
\text { different products } \\
\text { 4. Locations of SMEs that } \\
\text { are difficult to reach }\end{array}$ & $\begin{array}{l}\text { ST strategy } \\
\text { 1. Maintain and increase customer } \\
\text { satisfaction through quality } \\
\text { consistency, variety and innovation } \\
\text { of the products offered. } \\
\text { 2. Take advantage of strategic } \\
\text { locations and provide special } \\
\text { promos for customers to attract } \\
\text { customers } \\
\text { 3. There is a special center for MSME } \\
\text { products }\end{array}$ & $\begin{array}{l}\text { Efforts to improve the business } \\
\text { management system, quality of } \\
\text { human resources, intensive } \\
\text { marketing patterns, and } \\
\text { production technology are } \\
\text { needed to overcome existing } \\
\text { problems and existing business } \\
\text { competition. }\end{array}$ \\
\hline
\end{tabular}

Source: Results of data processing, 2020

\section{Conclusion}

The diversification strategy is considered more appropriate to be applied, because it is considered to be more appropriate to the current conditions in Gorontalo Regency. In addition, the use of the gig economy is part-time workers who are competent and innovative, this is according to our findings in the field where MSME businesses find it difficult to develop due to limited creativity because those who have creativity and innovation are business owners, 
which according to Our assessment is that this business owner will not be able to compete with other businesses that are more innovative and creative according to the times and consumer demands, this is in accordance with the demands of the MEA ERA which requires MSMEs to be more competitive.

\section{References}

Abraham, K., Haltiwanger, J., Sandusky, K., \& Spletzer, J. (2017). Measuring the gig economy: Current knowledge and open issues. Measuring and Accounting for Innovation in the 21st Century.

Hartomo, D. D., \& Cahyadin, M. (2013). Pemeringkatan Faktor Keberlangsungan Usaha Industri Kreatif di Kota Surakarta. Jurnal Ekonomi \& Kebijakan Publik, 4(2), 225236.

Johnston, H., \& Land-Kazlauskas, C. (2018). Organizing on-demand: Representation, voice, and collective bargaining in the gig economy. Conditions of work and employment series, 94.

Katyal, A., \& Xaviour, B. (2015). A study on MSMEs'-role in propelling economic development of India \& a discussion on current HR issues in MSMEs' in India. International Journal of Scientific and Research Publications, 5(2), 1-11.

Moleong, L. J. (2006). Metode penelitian kualitatif edisi revisi. Bandung: Remaja Rosdakarya.

Payu, B. R. (2013). Pemetaan UKM di Kota Gorontalo Berdasarkan Pola dan Tingkat Penggunaan Teknologi Informasi. Penelitian Unggulan Fakultas, 1(601).

Rahman, N. A. A., Muda, J., Mohammad, M. F., Ahmad, M. F., Rahim, S., \& Fernando, M. V. (2019). Digitalization and leap frogging strategy among the supply chain member: facing GIG economy and why should logistics players care. International Journal of Supply Chain Management, 8(2), 1042-1048.

Robson, P. J., \& Bennett, R. J. (2000). SME growth: The relationship with business advice and external collaboration. Small business economics, 15(3), 193-208.

Santosa, A. (2013). Perekonomian Indonesia: masalah, potensi, dan alternatif solusi. Graha Ilmu.

Tejasari, M. (2008). Peranan Sektor Usaha Kecil dan Menengah dalam penyerapan Tenaga Kerja dan Pertumbuhan Ekonomi. Thesis, Fakultas Ekonomi dan Manajemen. Institut Pertanian Bogor.

Wilantara, R. F., \& Susilawati, S. P. (2016). Strategi kebijakan pengembangan UMKM. Bandung: Refika Aditama. 